\title{
The Impact of translanguaging on The Chinese Language Speaking Skill
}

\author{
Tri Budianingsih \\ \{tri.budianingsih@uai.ac.id ${ }^{1}$ \} \\ Universitas Al Azhar Indonesia ${ }^{1}$
}

\begin{abstract}
This study aims to measure the learning outcomes of the first-level students' Chinese language speaking skills in one of the private universities in Jakarta by using the translanguaging approach. Nineteen students were involved and participated in this study. The researcher employed a speaking test with five assessment indicators, namely pronunciation, grammar, vocabulary, fluency level, and comprehension skill to obtain the information about the implementation of translangaging. This study was designed as a one-shot pre-experimental case study with one group given a treatment (treatment) and observed. The results of this study suggested that the students experienced an increase in speaking skills.
\end{abstract}

Keywords: translanguaging, Speaking Skill, Chinese Language

\section{Introduction}

The most important way of humans' communication is verbal communication. When people sense something, for example hearing, seeing or feeling something, they immediately wants to express it. Then, the cortical activity of the brain finds the right words in communication, which are stored in memory, and formed into sentences [1]. With that sense, learning a second language is, therefore, not easy. Brown (2007) mentioned several categories that must be understood in acquiring a second language, namely: learner characteristics, linguistic factors, learning process, age, instructional variables, context, and goals. As one of the mentioned categories, knowing the characteristics of the learners is very important because the teachers can determine the suitable teaching method for them, so that they can receive the materials easily [2].

One of the teaching methods that can be used in teaching Chinese language is translanguaging. This method maximizes the communicative potential between the students and the teacher, so that it can facilitate the teaching and learning process. In practice, translanguaging can be applied to understand the given text. For example, the teacher asks a question to the students by using Chinese language, then the students answer it by using Indonesian language. The aim of this process is to find out how deep the students' understanding toward the text is. Likewise, in speaking activities, sometimes the students do not really understand the context of the question, so that they cannot answer the question. Based on the examples above, translanguaging functions as a means to maximize the communication between the teacher and the students, so that the learning process can be maximized[3]. 


\section{Review Of Literature}

\subsection{Translanguaging}

Canagarajah (2011a) provides us with a definition of translanguaging as "the ability of multilingual speakers to shuttle between languages, treating the diverse languages that form their repertoire as an integrated system". The term translanguaging comes from the Welsh trawsieithu and was coined by [4]. Each of these scholars, however, defines translanguaging slightly differently. And yet, as the discussion of how these scholars treat "translanguaging" will show, the concept of translanguaging is based on radically different notions of language and bilingualism than those espoused in the 20th century, an epistemological change that is the product of acting and languaging in our highly technological globalized world. We start by tracing the development of the term translanguaging in its relationship to language and bilingualism[5].

\subsection{Billngual}

Haugen (1956) gave an early definition of the term bilingual: "Bilingual is a cover term for people with a number of different language skills, having in common only that they are not monolingual. Bilingual is one who knows two languages, but will here be used to include also the one who knows more than two, variously known as a plurilingual, a multilingual, or a polyglot." Uriel Weinreich (1974) provided a similar definition: "the practice of alternately using two languages will be called bilingualism, and the persons involved, bilingual'"[6].

\subsection{Speaking}

According to Cai Zhengyin, the assessment of speaking skills consists of two ways, namely individual assessment and peer or group assessment. In addition, the assessment of speaking Chinese language includes five (5) indicators, namely pronunciation 语音, grammar 语法, vocabulary 词汇, fluency level 流利 程度, and comprehension skill 理解 能力. The following table depicts the scoring system of the Chinese language speaking proficiency according to Cai Zhengyin[7].

Table 1. The Scoring System Of The Chinese Language Speaking Proficiency

\begin{tabular}{|c|c|c|c|c|c|}
\hline Score & $\begin{array}{c}\text { 语音 } \\
\text { (Pronunciation) }\end{array}$ & $\begin{array}{c}\text { 语法 } \\
\text { (Grammar) }\end{array}$ & $\begin{array}{c}\text { 词汇 } \\
\text { (Vocabulary) }\end{array}$ & $\begin{array}{c}\text { 流利程度 } \\
\text { (Fluency level) }\end{array}$ & $\begin{array}{c}\text { 理解能力 } \\
\text { (Comprehension } \\
\text { skill) }\end{array}$ \\
\hline $90-100$ & $\begin{array}{l}\text { Almost have no } \\
\text { mistake; very clear } \\
\text { for the sounds level } \\
1 \text { to } 4 \text { and the } \\
\text { pronunciation } \\
\text { "er"; almost perfect }\end{array}$ & $\begin{array}{l}\text { Have very few } \\
\text { mistakes on } \\
\text { the grammar } \\
\text { and word } \\
\text { order }\end{array}$ & $\begin{array}{l}\text { Almost have no } \\
\text { mistake in using } \\
\text { the words as } \\
\text { well as its } \\
\text { structure }\end{array}$ & $\begin{array}{l}\text { are very fluent and } \\
\text { proficient in } \\
\text { speaking }\end{array}$ & $\begin{array}{l}\text { Understand } \\
\text { almost all } \\
\text { questions and } \\
\text { explanation that } \\
\text { the teacher gives }\end{array}$ \\
\hline $80-90$ & $\begin{array}{l}\text { Is not clear enough; } \\
\text { not really able to } \\
\text { differentiate the }\end{array}$ & $\begin{array}{l}\text { Sometimes } \\
\text { occur few } \\
\text { mistakes on }\end{array}$ & $\begin{array}{l}\text { Sometimes } \\
\text { occur few } \\
\text { mistakes on the }\end{array}$ & $\begin{array}{l}\text { Experience few } \\
\text { difficulties to } \\
\text { handle the pauses; }\end{array}$ & $\begin{array}{l}\text { Generally able to } \\
\text { understand the } \\
\text { teacher's }\end{array}$ \\
\hline
\end{tabular}


difficult consonants the grammar and vowels, e.g., zh, ch, sh, r; z, c, s; an, ang; en, eng etc

$60-80$

Have some
mistakes to be
repaired; need extra
focus while
listening to the
speaking of the
counterparts to
really understand
the meaning.

Below Perform many

60 wrong

pronunciation; not able to understand the purpose of the counterpart's speaking; need repetition; have less ability to communicate with the counterparts and word

order, but not

too influential

on the

speaker meaning of the

unsuitable word placement; the vocabulary

range that is not many; still can

use some words to replace the expected words, which do not influence the meaning of the speaker

Often occur Often occur mistakes on misuse of the the grammar and word order, which are influential to the meaning of the speaker

\begin{tabular}{|c|c|}
\hline $\begin{array}{l}\text { Very often } \\
\text { occur mistakes } \\
\text { on the } \\
\text { grammar and } \\
\text { word order; } \\
\text { often avoid the } \\
\text { conversation } \\
\text { even when it is } \\
\text { expressed by } \\
\text { simple } \\
\text { expressions; } \\
\text { hardly } \\
\text { understand the } \\
\text { expressions }\end{array}$ & $\begin{array}{l}\text { Perform less } \\
\text { talk and not able } \\
\text { to communicate } \\
\text { with the } \\
\text { counterparts due } \\
\text { to the limited } \\
\text { vocabulary } \\
\text { range and ability } \\
\text { to use the proper } \\
\text { words }\end{array}$ \\
\hline
\end{tabular}

words; lack of vocabulary range still stammering in explanation; speaking sometimes ask the teacher to repeat it to really understand it
Feel nervous when Mostly able to speaking; perform understand the unstable speed or teacher's fluency rate; feel explanation; need quite difficult to some repetitions express the from the teacher meaning and to understand it purpose of the speaking

Do not know what Is very difficult to speak and how to understand the to express it; do teacher's not know when to explanation; need intervene the slow explanation speaking; unstable rate from the speed or fluency teacher to really rate; basically not understand it; able to often ask the communicate with teacher to slowly the counterparts repeat it by using simple words and expressions

Suggested various activities that can support the students' speaking skills improvement in the learning process, namely: 1) Acting from a script, 2) Communication games, 3) Discussion, 4) Prepared talks, 5) Questionnaires, and 6) Simulation and roleplay[4]. While, Pattison in Nunan (1989) designed several activities that can be applied in speaking classes, namely 1) questions and answers, 2) dialogues and role-plays, 3) matching activities, 4) communication strategies, 5) pictures and picture stories and 6 ) puzzles and problems.

\section{Method}

This study is designed as a one-shoot pre-experimental case study. This design involved one group given a treatment and being observed. When the observation was made, the 
researcher acted as the lecturer by using a conventional method. In addition, the researcher made an observation guideline to see the observed aspects. This was done before the research group was given a pre-test. Then the post-test was carried out after the treatment to assess the students' speaking skills. The purpose of the test is to determine the impact of translanguaging on their learning of speaking skill[8].

The population of this study was the second-semester students of the Chinese Literature Study Program in the 2016/2017 academic year, Al-Azhar University, Indonesia. A class consisting of 19 students were involved as the participants. Because the population is very small, the researcher did not do random sampling, so that all of the students were involved and participated in this study.

This study employed a speaking test with five (5) assessment indicators, namely pronunciation (20\%), grammar (20\%), vocabulary (20\%), fluency level (20\%), and comprehension skill (20\%). This test was used during the post-test with an objective assessment, which consists of three types of exercises, namely retelling (20\%), question and answer $(10 \%)$, and telling about a simple picture $(20 \%)$. The pretest was done before the treatment and after the observation, while the posttest was done after the treatment. The test was used to obtain information about the application of translanguaging in Chinese speaking skills viewed from the students' learning outcomes.

To analyze the tests results, the researcher employed descriptive analysis to determine the percentage of the students' learning outcomes with translanguaging. Meanwhile, to know the difference in the learning outcomes between before and after the treatment, it is necessary to do a statistical test. It is needed to see the difference between the pre-test and post-test results. Specifically, t-test was used with the following formula.

$$
t_{0}=\frac{M_{D}}{S E_{M o}}
$$

In addition to the t-test, the researcher also conducted the normality and homogeneity tests. The former was performed to determine whether the selected sample distribution comes from a normal or abnormal population distribution. Meanwhile, the homogeneity test was performed to determine the diversity of the same values in the data and whether there is a various variance or standard deviation from the data. Homogeneity of the data becomes one of the requirements recommended for statistical testing, especially when using parametric statistics, such as t-test and f-test.

\section{Results}

The results of the research before and after the treatment are as follows.

Table 2. Scores of pretest (after observation)

\begin{tabular}{ccccc}
\hline No & $\mathbf{N}$ & The lowest score (pretest) & The highest score (pretest) & Average score (pretest) \\
\hline 1 & 19 & 51 & 90,5 & 77,82 \\
\hline
\end{tabular}

The obtained data before the treatment showed the lowest score as much 51 , while the highest score as much 90.5 and the average score as much 77.82 .

Table 3 depicts the result of the posttest. 
Table 3. Scores of posttest (after the treatment)

\begin{tabular}{ccccc}
\hline No & $\mathbf{N}$ & The lowest score (posttest) & The highest score (posttest) & Average score (posttest) \\
\hline $\mathbf{1}$ & 19 & 64 & 96 & 82,16 \\
\hline
\end{tabular}

The obtained data after the treatment showed the lowest score as much 64 , while the highest score as much 96 and the average score as much 82.16.

\subsection{Normality Test}

The normality test was done by using the Lilliefors test by testing the null hypothesis. The sample comes from a population with normal distribution. The statistical hypothesis used is $\mathrm{H} 0=\mathrm{L}$-count $<\mathrm{L}$-table and $\mathrm{H} 1=\mathrm{L}$-count $>\mathrm{L}$-table. The test results indicate that the sample comes from a population with normal distribution. The following table depicts the summary of the Lilliefors test results.

Table 4. The results of normality test by using Lilliefors test

\begin{tabular}{clcc}
\hline No & \multicolumn{1}{c}{ Item } & After observation (pretest) & After treatment (posttest) \\
\hline $\mathbf{1}$ & Average & 77,82 & 82,16 \\
$\mathbf{2}$ & Standard deviation & 14,4474 & 9,6221 \\
$\mathbf{3}$ & Number of students & 19 & 19 \\
$\mathbf{4}$ & L-count & 0,181 & 0,111 \\
$\mathbf{5}$ & L-table & 0,195 & 0,195 \\
$\mathbf{6}$ & Significance level & 0,05 & 0,05 \\
\hline
\end{tabular}

Because the L-count is smaller than the L-table, Ho is accepted. Thus, the sample in the pretest and posttest experimental class comes from the population with normal distribution.

\subsection{Homogeneity Test}

The homogeneity test in this study was carried out by using the F-Test because both data are not going to be correlated (independent). The following table depicts the results of the FTest on the pretest and posttest.

Table 5. The results of homogeneity test on the pretest and posttest

\begin{tabular}{cccccc}
\hline Group & N & Sum & S2 & F-count & F-table \\
\hline Pretest & 19 & 1478,5 & 208,73 & 2,25 & 3,19 \\
Posttest & 19 & 1561 & 92,58 & & \\
\hline
\end{tabular}

Because the F-count (2.25) <F-table (3.19), the population variance between group 1 and group 2 is homogeneous.

This study continued to test the difference between the two average scores to test the null hypothesis that there was a significant difference between the mean of pretest and posttest. The test used is t-test. The following table depicts the result of the t-test. 
Table 6. The result of the t-test on the difference between both average scores

\begin{tabular}{ccccccccc}
\hline Group & N & Sum & D $(\mathbf{X 1 - X 2})$ & D2 & MD & SEMD & t-count & t-table $=\mathbf{0 , 0 5}$ \\
\hline $\begin{array}{l}\text { Pretest } \\
\text { Posttest }\end{array}$ & 19 & $\begin{array}{c}1478,5 \\
1561\end{array}$ & 83 & 1715 & 4,34 & 1,99 & 2,18 & 1,73 \\
\hline
\end{tabular}

The results show that the t-count is more than the t-table. Thus, it can be concluded that with a one-sided test at a significant level of 0.05 with $n-1=18$ as much 1.73 and the $t$-count $(2.18)>t$-table (1.73), it means that there is a significant increase between the results of UTS (mid-term exam) and UAS (final-term exam) of Chinese speaking skills. Thus, the impact of translanguaging on the improvement of students' Chinese language skills is more effective.

\section{Conclusion}

From the results of the treatment tests before and after pretest and posttest, it can be identified that the results of both tests have significant difference. The data obtained from the pretest showed the lowest score as much 51, while the highest score as much 90, 5, and the average score as much 77.82. Meanwhile, the posttest results showed the lowest score as much 64, while the highest score as much 96, and the average score as much 82.16. Therefore, both samples come from normal distribution. In addition, from the homogeneity test, the results also show that the F-count (2.25) is smaller than the F-table (3.19). It means that both groups have similar or homogeneous variance. Furthermore, the t-test was carried out to find out the difference between both tests' average scores to test the null hypothesis. The results show that the t-count (2.18) is greater than the t-table (1.73). It can be concluded that the difference is significant meaning that $\mathrm{H} 0$ is rejected and $\mathrm{H} 1$ is accepted. Thus, the impact of translanguaging on the first-level students' Chinese language speaking skills is more effective.

It is recommended that the Chinese language teachers can be more creative to use techniques that are appropriate for learning the language and can make the students participate in the classroom. As a result, all of them can understand the materials. The limitation of this study lies on the duration of applying the treatment, which is only six times. Therefore, it is recommended that there should be further research with more time to practice the skills.

\section{References}

[1] YuanHuiYang., Ketang Jiaxue Lilun Yu Shijian. Beijing: BLCU Press, 2007.

[2] T. Budianingsih, "Quantum-based approach for learning spoken mandarin: a model of teaching material," 2018, pp. 159-165.

[3] B. H. Douglas, Prinsip Pembelajaran dan Pengajaran Bahasa. Jakarta: Kedutaan Besar Amerika Serikat., 2007.

[4] J. Hamer, The Practice of English Teaching. England. Person Education Limited., 2001.

[5] O. G. Wei, Translanguaging. America: Palgrave Macmillan., 2014.

[6] Kadir, Statistika; untuk ilmu-ilmu sosial. Jakarta: Rosemata Sampurna., 2010.

[7] C. Z. Ying, Hanyu kouyuke jiaoxuefa. Beijing: BLCU, 2009.

[8] D. Nuna, Desiging Task for the Communicative Classroom. Cambridge. Cambridge: Cambridge University., 1989. 